www.jmscr.igmpublication.org

Impact Factor 5.244

Index Copernicus Value: 83.27

ISSN (e)-2347-176x ISSN (p) 2455-0450

crossref DOI: _https://dx.doi.org/10.18535/jmscr/v4i10.74

\author{
Journal Of Medical Science And Clinical Research \\ IGM Publication \\ An official Publication of IGM Publication
}

\title{
Cytological Correlation of Benign Breast Diseases with Histopathology
}

\author{
Authors \\ Shilpa $\mathbf{N}^{1}$, Shridevi $\mathbf{S} \mathbf{H}^{2}$ \\ ${ }^{1}$ Pathologist, Shimoga Institute of Medical Sciences Shimoga, Karnataka, India \\ ${ }^{2}$ Assistant professor, Vijayanagar Institute of Medical Sciences, Bellary, Karnataka, India \\ Corresponding Author \\ Shilpa N \\ Email-drshilpanandan@gmail.com
}

\begin{abstract}
Fine needle aspiration cytology (fnac) has become the popular diagnostic tool in preoperative assessment of breast masses and it has high diagnostic accuracy, sensitivity and specificity. The major goal of fnac is to differentiate benign lesion which is managed conservatively from the malignant one which need radical therapy.] Present study is undertaken to the distribution of the various benign breast diseases by cytology. Cytological with histopathological reports correlation was done to know the diagnostic accuracy of fnac. Materials and Methods: Present study included cytology of 88 breast lesions with histopathological correlation. It is retrospective and prospective study. Results are expressed in descriptive data, percentages and diagnostic accuracy was calculated by comparing cytological and histopathological reports.

Results: The study included 88 breast cases, which were diagnosed as benign on cytology. Fibroadenoma was the commonest benign breast disease. The diagnostic accuracy of fine needle aspiration in diagnosing benign breast lesion is $96.6 \%$ with false negative rate of $3.4 \%$.

Discussion and Conclusion: In present study fibroadenoma is the most common benign breast disease, which is in accordance with previous studies. Maximum number of cases was in the age group between 20 to 29 years which correlates with the previous literature that benign breast disease are more common in young adults.The diagnostic accuracy and false negative rate of cytology in detecting benign breast masses is comparable to most of the previous studies.
\end{abstract}

Keywords-Fibroadenoma, Fibrocystic disease, Phylloides tumour, Fine needle aspiration cytology, Mastitis.

\section{INTRODUCTION}

Fine needle aspiration cytology (fnac) has become the popular diagnostic tool in preoperative assessment of breast masses and it has high diagnostic accuracy, sensitivity and specificity. ${ }^{[1]}$ The major goal of fnac is to differentiate benign lesion which is managed conservatively from the malignant one which need radical therapy. In the evaluation of breast masses, time honoured widely accepted triple assessment which combines clinical, radiological and pathological details has profound impact on surgical intervention. ${ }^{[2], ~}{ }^{[3]}$ Fnac is rapid and can be performed safely with very minimal complications. Most of the benign breast diseases can be detected cytologically with high diagnostic accuracy. Nevertheless, in fnac of breast there are instances where the differentiation of benign and malignant is not possible yielding few false negative 
and false positive results. According to literature false negative rate ranges from 1.2 to $10.6 \%$. ${ }^{\text {[2] }}$ This problem arises when there is inadequate sampling or there is morphological overlap between benign and malignant. ${ }^{[4]}$ Present study is undertaken to the distribution of the various benign breast diseases by cytology.

\section{MATERIALS AND METHODS}

Present study included cytology of 88 breast lesions with histopathological correlation. It is retrospective and prospective study. In prospective, the patients referred to pathology lab with breast mass were examined. Fnac was done after explaining the procedure. In non-palpable breast masses ultrasound guided fnac was done. One slide was air dried and Giemsa stain was done. Remaining slides were fixed in $95 \%$ alcohol and stained with H\&E. Special stain was done whenever necessary. The respective post -operative specimens were fixed in $10 \%$ formalin. After adequate fixation representative bits were given. Histopathological examination was done. In retrospective cases the fnac and histopathological slides were obtained from archives and related demographic data were collected. Only benign cases on cytology were included in the study. The cases which were suspicious for malignancy or inadequate sample size were excluded from study. Results are expressed in descriptive data, percentages and diagnostic accuracy was calculated by comparing cytological and histopathological reports.

\section{RESULTS}

The study included 88 breast cases, which were diagnosed as benign on cytology. The distribution of cases according to age is given in graph 1. Most of the cases were clustered in the age between 20-29 years (39cases).
Graph 1: Age distribution of patients with breast lesions

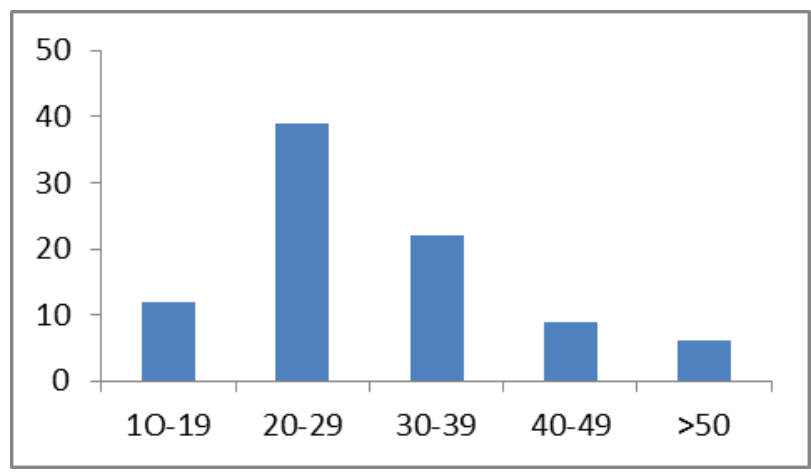

The size of the lesion ranges from $1 \mathrm{~cm}$ to $7 \mathrm{~cm}$. The distribution of benign breast diseases is given in table 1. Fibroadenoma is the most common lesion encountered amounting to $55.68 \%$.

Table 1: Cytological Diagnoses of Breast diseases included in the study

\begin{tabular}{|l|l|}
\hline Cytological diagnosis & $\begin{array}{l}\text { No of cases } \\
(\mathrm{n}=88)\end{array}$ \\
\hline Fibroadenoma & $49(55.68 \%)$ \\
\hline Fibrocystic breast disease & $18(20.45 \%)$ \\
\hline Proliferative breast disease & $10(11.36 \%)$ \\
\hline Benign cysts & $3(3.40 \%)$ \\
\hline Phylloides tumour & $2(2.27 \%)$ \\
\hline Chronic non specific Mastitis & $2(2.27 \%)$ \\
\hline Granulomatous mastitis & $2(2.27 \%)$ \\
\hline Fat necrosis & $1(1.13 \%)$ \\
\hline Tuberculous mastitis & $1(1.13 \%)$ \\
\hline
\end{tabular}

Comparison of cytological reports with histopathology is given in table 2. Out of 88 benign lesions of cytology, 3 cases were diagnosed as malignancy on histopathology. Amongst 49 cases of fibroadenoma, 47 were proved on histopathology. Two cases of fibroadenoma and one case of fibrocystic disease had features of both fibroadenoma and fibrocystic disease on histopathology. A case of benign proliferative breast disease was later diagnosed as infiltrating duct carcinoma on histopathology. A case of cyst which had protienaceous fluid in the back ground with few degenerated and ductal cells, on histopathology showed large pools of mucin embedding small clusters of tumour cells with final diagnosis of mucinous carcinoma. A case of phylloides tumour on cytology had malignant phylloides features on histopathology 
Table 2: Histopathological correlation of cases diagnosed as benign on cytology

\begin{tabular}{|l|c|c|}
\hline Breast diseases & $\begin{array}{c}\text { Cytology } \\
(\mathrm{n}=88)\end{array}$ & $\begin{array}{c}\text { Histopatholo } \\
\text { gy (n=88) }\end{array}$ \\
\hline Fibroadenoma & 49 & 47 \\
\hline Fibrocystic disease & 18 & 17 \\
\hline $\begin{array}{l}\text { Fibroadenoma with fibrocystic } \\
\text { change }\end{array}$ & 0 & 3 \\
\hline $\begin{array}{l}\text { Benign proliferative breast } \\
\text { disease }\end{array}$ & 10 & 9 \\
\hline Cysts & 3 & 2 \\
\hline Phylloides tumour & 2 & 1 \\
\hline Chronic nonspecific mastitis & 2 & 2 \\
\hline Granulomatous mastitis & 2 & 2 \\
\hline Fat necrosis & 1 & 1 \\
\hline Tuberculous mastitis & 1 & 1 \\
\hline Infiltrating duct carcinoma & 0 & 1 \\
\hline Mucinous carcinoma & 0 & 1 \\
\hline Malignant phylloides & 0 & 1 \\
\hline
\end{tabular}

The diagnostic accuracy of fine needle aspiration in diagnosing benign breast lesion is $96.6 \%$ with false negative rate of $3.4 \%$

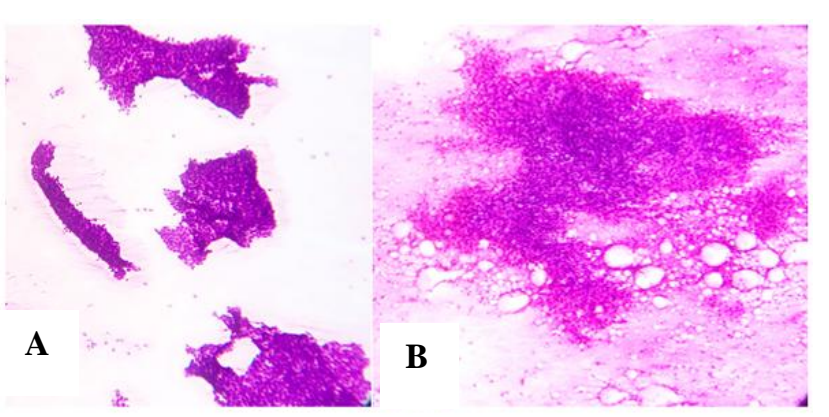

Figure 1. Cytology of benign proliferative breast disease (A), and granulomatous mastitis (B), H\&E, LP.

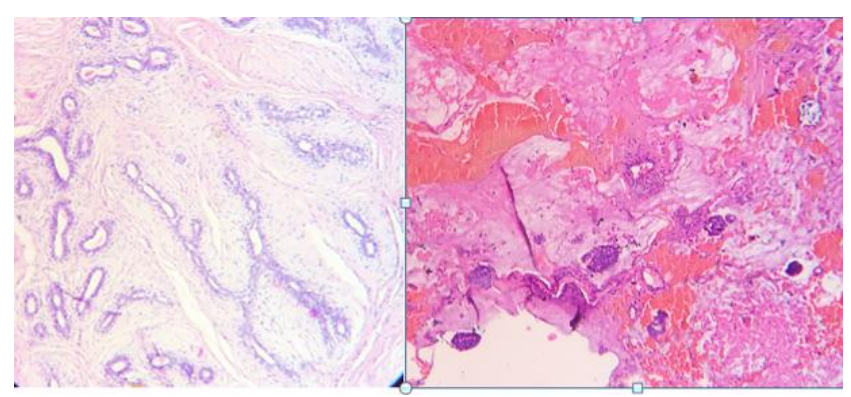

Figure 2. Histopathology of fibroadenoma(C) and mucinous carcinoma, with large mucin filled areas with few malignant cells which gave false negative result on cytology (D), H\&E, LP.

\section{DISCUSSION}

In present study fibroadenoma is the most common benign breast disease, which is in accordance with previous studies. Maximum number of cases was in the age group between 20 to 29 years which correlates with the previous literature that benign breast disease are more common in young adults. ${ }^{[5]-}$ [7] Evaluation of breast masses in the context of triple assessment fnac has significantly resulted in excisional biopsies. However there still exist quite significant false negative rate for fnac which range from 1.2 to $10.2 \%$.this may lead to delayed or missed diagnosis and treatment, sometimes with adverse clinical outcome. ${ }^{[2]}$ In present study the diagnostic accuracy of cytology in detecting benign breast masses is $96.6 \%$, which is comparable to most of the previous studies. The false negative rate in the present study is $3.4 \%$, the comparison of which with previous studies is given in table 3 .

Table3. Cyto-histopathological correlation \& statistical evaluation of benign breast lesions

\begin{tabular}{|l|c|c|c|}
\hline Studies & \multirow{2}{*}{$\begin{array}{c}\text { Benign } \\
\text { lesions }\end{array}$} & \multicolumn{2}{|c|}{ Histopathology } \\
\cline { 3 - 4 } & 382 & $\begin{array}{c}374 \\
(97.9 \%)\end{array}$ & $\begin{array}{c}8 \\
(2.1 \%)\end{array}$ \\
\hline Ishiwaka et al $^{[8]}$ & 60 & $\begin{array}{c}59 \\
(98.33 \%)\end{array}$ & $\begin{array}{c}1 \\
(1.17 \%)\end{array}$ \\
\hline $\begin{array}{l}\text { Ambedkar et al } \\
\text { 77] }\end{array}$ & 60 & $\begin{array}{c}153 \\
(92.17 \%)\end{array}$ & $\begin{array}{c}13 \\
(7.83 \%)\end{array}$ \\
\hline O’Neil S et al[9] & 166 & $\begin{array}{c}213 \\
(99.07 \%)\end{array}$ & $\begin{array}{c}2 \\
(0.93 \%)\end{array}$ \\
\hline $\begin{array}{l}\text { Zhang Qin et al } \\
{[10]}\end{array}$ & 215 & $\begin{array}{c}58 \\
(95.08 \%)\end{array}$ & $\begin{array}{c}3 \\
(4.92 \%)\end{array}$ \\
\hline $\begin{array}{l}\text { A Mohammed } \\
\text { et al }\end{array}$ & $611]$ & $\begin{array}{c}45 \\
(97.83 \%)\end{array}$ & $\begin{array}{c}1 \\
(2.17 \%)\end{array}$ \\
\hline $\begin{array}{l}\text { S I Panjvani et } \\
\text { al }\end{array}$ & $46]$ & $\begin{array}{c}85 \\
(96.6 \%)\end{array}$ & $\begin{array}{c}3 \\
(3.4 \%)\end{array}$ \\
\hline Present Study & 88 & &
\end{tabular}

The causes for false negativity which are discussed in previous literature are divided into diagnostic errors and true false negative factors. Diagnostic errors include lack of training overload miscorrelation of patient clinical and radiological findings. True false negative factors are poor sampling techniques, miss-localisation, tumour with minimal nuclear atypia and tumour with large cystic component. ${ }^{[2]}$ Fnac has got diagnostic dilemma in diagnosing fibrocystic disease, adenosis, papilloma, 
cystic tumour, papillary carcinoma with minimal nuclear atypia which may have to be adjunct with imaging features to exclude malignancy ${ }^{[12]}$.

\section{CONCLUSION}

The present study are in terms with the previous studies that benign breast diseases were the most common lesions in young females, among which fibroadenoma were commonest. Fnac has become widely accepted tool in diagnosing benign breast diseases as it is simple, safe with high diagnostic accuracy.Most of the patients with breast lumps are in state of anxiety. Fnac is very helpful in reducing anxiety, avoid delay in diagnosis and minimise surgical intervention. False negative rates are inevitable which is overcome by trouble shooting diagnostic errors

\section{REFERENCES}

1. Koss LG. The palpable breast nodule: a cost effectiveness and analysis of alternate diagnostic approaches: the role of the needle aspiration biopsy. Cancer 1993;72:1499502.

2. Mendoza P, Lacambra M, Tan PH, Tse GM, Fine needle aspiration cytology of the breast: the non malignant categories, Pathol Res Int. 2011;2011:547580. doi: 10.4061/2011/547580. Available from https://www.hindawi.com/journals/pri/2011/547580/

3. Morris KT, Pommier RF, Morris A, Schmidt WA, Beagle G, Alexander PW, Toth-Fejel S, Schmidt J, Vetto JT. Usefulness of the triple test score for palpable breast masses. Archives of Surgery. 2001 Sep 1;136(9):1008-13.

4. Park IA, Ham EK . Fine needle aspiration cytology of palpable breast lesions. Histologic subtype in false negative cases. Acta Cytol 1997; 41:1131-8.

5. Schnitt SJ. Benign breast disease and breast cancer risk: morphology and beyond. Am J Surg Pathol 2003;27:836.
6. Dixon et al. Fine needle aspiration cytology in relationship to clinical examination and mammography in the diagnosis of a solid breast mass. British Journal of Surgery 1978; 71:593-596.

7. Ambedkar R K, Srinivasamurthy B C, Rani J. Cytological evaluation of benign breast lesions with histopathological correlation, Ind J Pathol Oncol 2016;3(1);7-10

8. 8.Ishikawa T, Hamaguchi $\mathrm{Y}$, TanabeL M, False-positive and false-negative cases of fine-needle aspiration cytology for palpable breast lesions, Breast cancer 2007;14(4): 388-392.

9. O’Neil S, Castelli M, Gattuso P, Kluskens L, Madsen K, Aranha G. Fine-needle aspiration of 697 palpable breast lesions with histopathologic correlation. Surgery. 1997; 122(4): 824-28.

10. Zhang Qin, Nie Shigui, Chen Yuhua, Zhou Limei. Fine Needle Aspiration Cytology of Breast Lesions: Analysis of 323 Cases. The Chinese-German Journal of Clinical Oncology. 2004; 3(3): 172-74.

11. Mohammad AZ, Edino ST, Ochicha O, Alhassan SU. Value of fine needle aspiration biopsy in preoperative diagnosis of palpable breast lumps in resource- poor countries: a Nigerian experience. Annals of African Medicine. 2005; 4(1): 19-22.

12. Sahil I. Panjvani et al., Utility of Fine Needle Aspiration Cytology in the Evaluation of Breast Lesions, J Clin Diagn Res. 2013;7(12): 2777-2779 